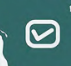

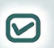

\title{
New record and update on the geographic distribution of Enyalius bilineatus Duméril \& Bibron, 1837 (Squamata: Leiosauridae) in Brazil
}

\author{
Raul Fernandes Dantas Sales ${ }^{1 *}$, Leonardo Barros Ribeiro ${ }^{2}$ and Eliza Maria Xavier Freire ${ }^{1}$ \\ 1 Universidade Federal do Rio Grande do Norte, Centro de Biociências, Departamento de Botânica e Zoologia, Laboratório de \\ Herpetologia, Campus Universitário, Lagoa Nova, CEP 59078-970, Natal, RN, Brazil \\ 2 Universidade Federal do Vale do São Francisco, Campus Ciências Agrárias, BR 407 km 12, Lote 543, Distrito de Irrigação Senador Nilo \\ Coelho, CEP 56300-990, Petrolina, PE, Brazil \\ * Corresponding author. E-mail: raulsales17@gmail.com
}

\begin{abstract}
Herein, we provide the first record of Enyalius bilineatus for the Caatinga region, northeastern Brazil, and an updated distribution map based on literature and museum records. We collected two specimens of E. bilineatus at Serra do Barbado, northern region of the Espinhaço mountain ridge ("Chapada Diamantina" plateau complex), Bahia, Brazil. This new record extends the known geographic distribution of E. bilineatus 716 $\mathrm{km}, 462 \mathrm{~km}$, and $590 \mathrm{~km}$ from the closest known localities in the southwest, southeast, and south, respectively.
\end{abstract}

Keywords: Caatinga; Chapada Diamantina; highlands; lizards

Leiosaurid lizards are distributed along South America, from southern Amazonia to Patagonia, through Cerrado and Atlantic Forest (Vitt and Caldwell 2014). The genus Enyalius currently includes ten species of arboreal to semi-arboreal forest dwellers, associated with tropical and subtropical forests in Brazil (Rodrigues et al. 2014). Enyalius bilineatus Duméril \& Bibron, 1837 has a relatively broad distribution when compared to other congeneric species, occurring at high elevations in the Atlantic Forest in the states of Rio de Janeiro (Jackson 1978), Espírito Santo (Zamprogno et al. 2001; Teixeira et al. 2005), and Minas Gerais (Vanzolini 1978; Bertoluci et al. 2009; Costa et al. 2009; Sousa et al. 2010; Gomides and Sousa 2012; Moura et al. 2012; Novelli et al. 2012; Borges et al. 2013), and in gallery forests in the Cerrado of Central Brazil (Rodrigues et al. 2006; Nogueira et al. 2011). Lizards of this species are sexually dimorphic in size (females larger than males), sit-and-wait foragers, and feed upon ground arthropods in general, despite their scansorial habits (Zamprogno et al. 2001; Teixeira et al. 2005).
Herein, we provide the first record of E. bilineatus for the Caatinga region, northeastern Brazil, and an updated distribution map based on literature and museum records. To build the map, we made an extensive search in the literature in on-line bibliographic databases (Web of Science JSTOR, Scielo, Scopus, and Google Scholar), looking for records of the species. Additionally, we also obtained records in the SpeciesLink database (http://www.splink.cria.org.br) from three Brazilian herpetological collections (UFRM-REP: Coleção de Répteis do Centro de Coleções Taxonômicas da Universidade Federal de Minas Gerais; MBML-Repteis: Coleção de Répteis do Museu de Biologia Professor Mello Leitão; MCP-Repteis: Coleção de Répteis da Pontifícia Universidade Católica do Rio Grande do Sul). All localities with geographic coordinates are in the Appendix. We georeferenced using Google Earth some localities whose geographical coordinates were not provided by authors.

On 6 September 2014, during a fieldwork at the northern region of the Espinhaço mountain ridge ("Chapada Diamantina" plateau complex), Serra do Barbado, Abaíra, Bahia ( $13.2874^{\circ} \mathrm{S}, 041.8905^{\circ} \mathrm{W} ; 1,247$ $\mathrm{m}$ above sea level), we collected two specimens of $E$. bilineatus (UFRN 4449: male, $71.6 \mathrm{~mm}$ SVL, $208.6 \mathrm{~mm}$ tail length, Figure 1a; UFRN 4500: female, $72.7 \mathrm{~mm} \mathrm{SVL}$, $181.6 \mathrm{~mm}$ tail length, Figure $1 \mathrm{~b}$ ). The physiognomy in the area is a mix of campos rupestres and cerrado vegetation. We found the two lizards on the leaf litter under shrubs. We identified the specimens as E. bilineatus based on the key to species of Enyalius presented by Rodrigues et al. (2006). Both specimens presented the following diagnostic characters: infradigital lamellae smooth (Figure 2a), ventral scales keeled (Figure 2b), a distinctive and enlarged subocular present (Figure $2 \mathrm{c}$ ), canthus 


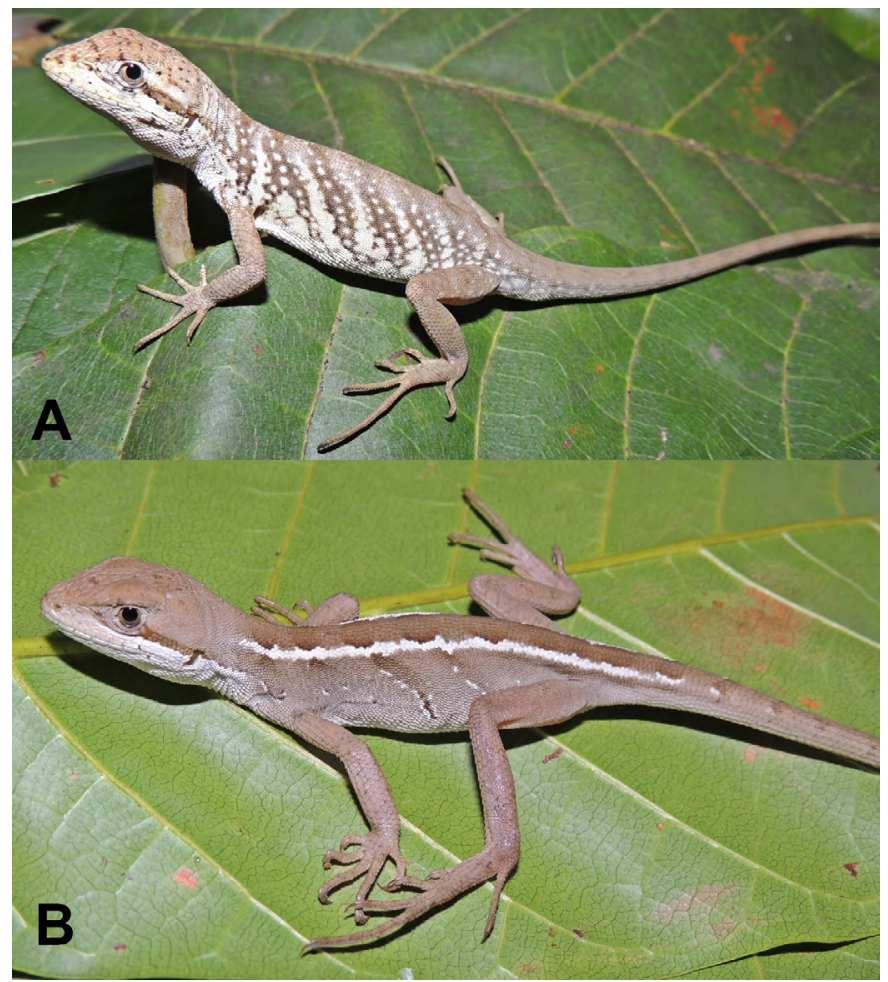

Figure 1. Specimens of Enyalius bilineatus collected in the Serra do Barbado, Abaíra, Bahia, Brazil. A: UFRN 4449, male, $71.6 \mathrm{~mm}$ SVL. B: UFRN 4500, female, $72.7 \mathrm{~mm} \mathrm{SVL).}$ rostralis straight (Figure $2 \mathrm{~d}$ ), and tail longer than 2.4 times SVL (2.9 times in UFRN 4449 and 2.5 times in UFRN 4500). We identified the sex of specimens by direct examination of gonads. Their distinct coloration (Figure 1) indicates the existence of color polymorphism in the population, but is probably not related with sexual dichromatism, which is considered to be absent in this species (Rodrigues et al. 2006). Specimens were collected under permanent permit number 12734-1, issued by Sisbio/ICMBio, and were housed in the Herpetological Collection of the Universidade Federal do Rio Grande do Norte (voucher numbers: UFRN 4499-4500). M.T. Rodrigues verified the identification of both specimens.

We found 25 records in the literature in the states of Goiás, Espírito Santo, Minas Gerais, Rio de Janeiro, and Distrito Federal (Figure 3; Appendix). Additionally, we also obtained 18 localities from the SpeciesLink database (Figure 3; Appendix). Most records are concentrated in the Atlantic Forest of Minas Gerais. Some authors (e.g., Nogueira et al. 2011; Guedes et al. 2014) advise not to use occurrence data from electronic databases in studies on geographic distribution without careful examination of deposited vouchered material, so we differentiate in the map occurrence points in the literature and SpeciesLink
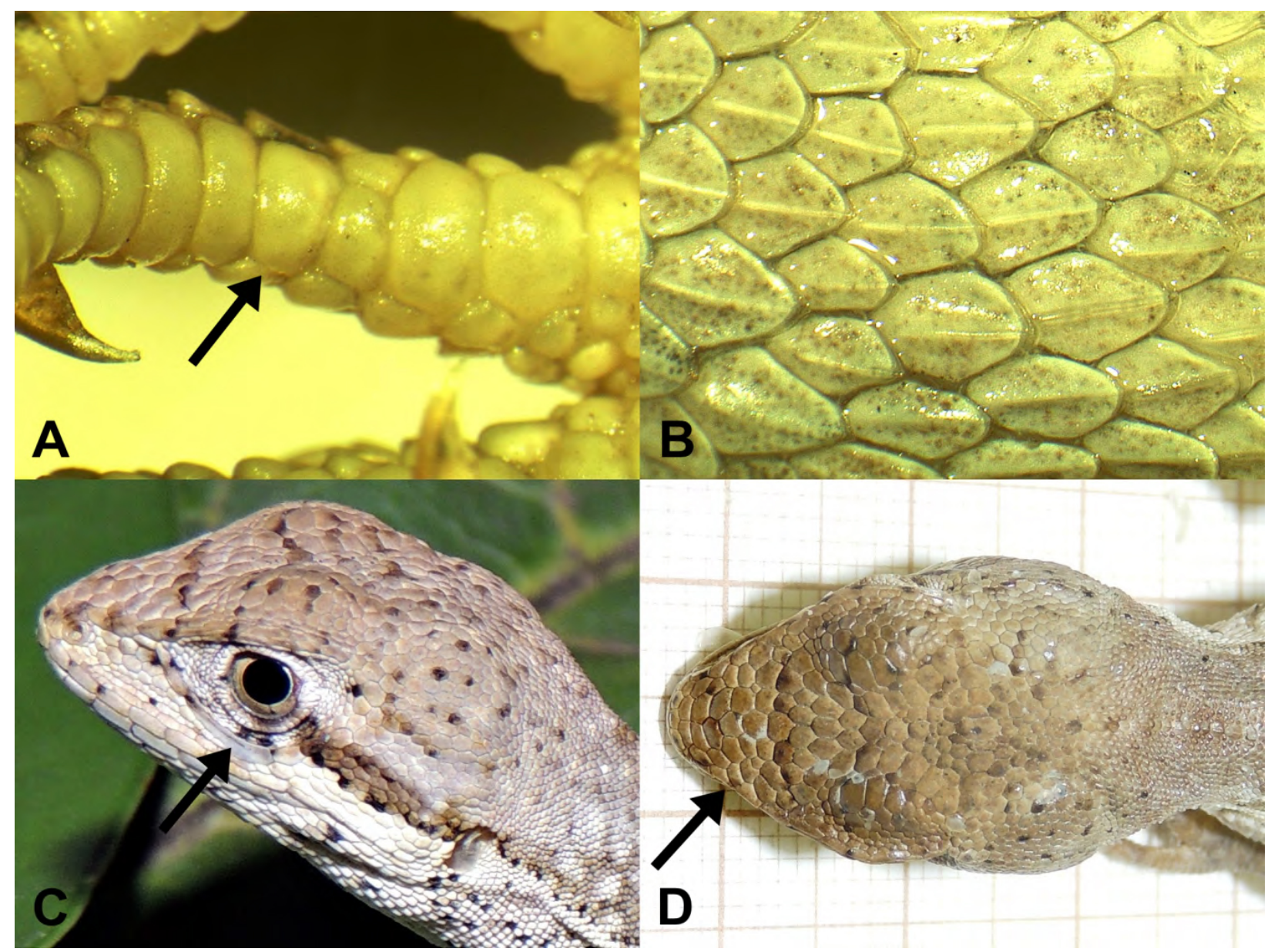

Figure 2. Partial views of UFRN 4449, showing some diagnostic characters of Enyalius bilineatus: (A) fourth finger of right hindlimb, showing infradigital lamellae smooth; (B) ventral view of midbody, showing ventral scales keeled; (C) lateral view of the head, showing a distinctive and enlarged subocular present; and (D) dorsal view of the head, showing canthus rostralis straight. 


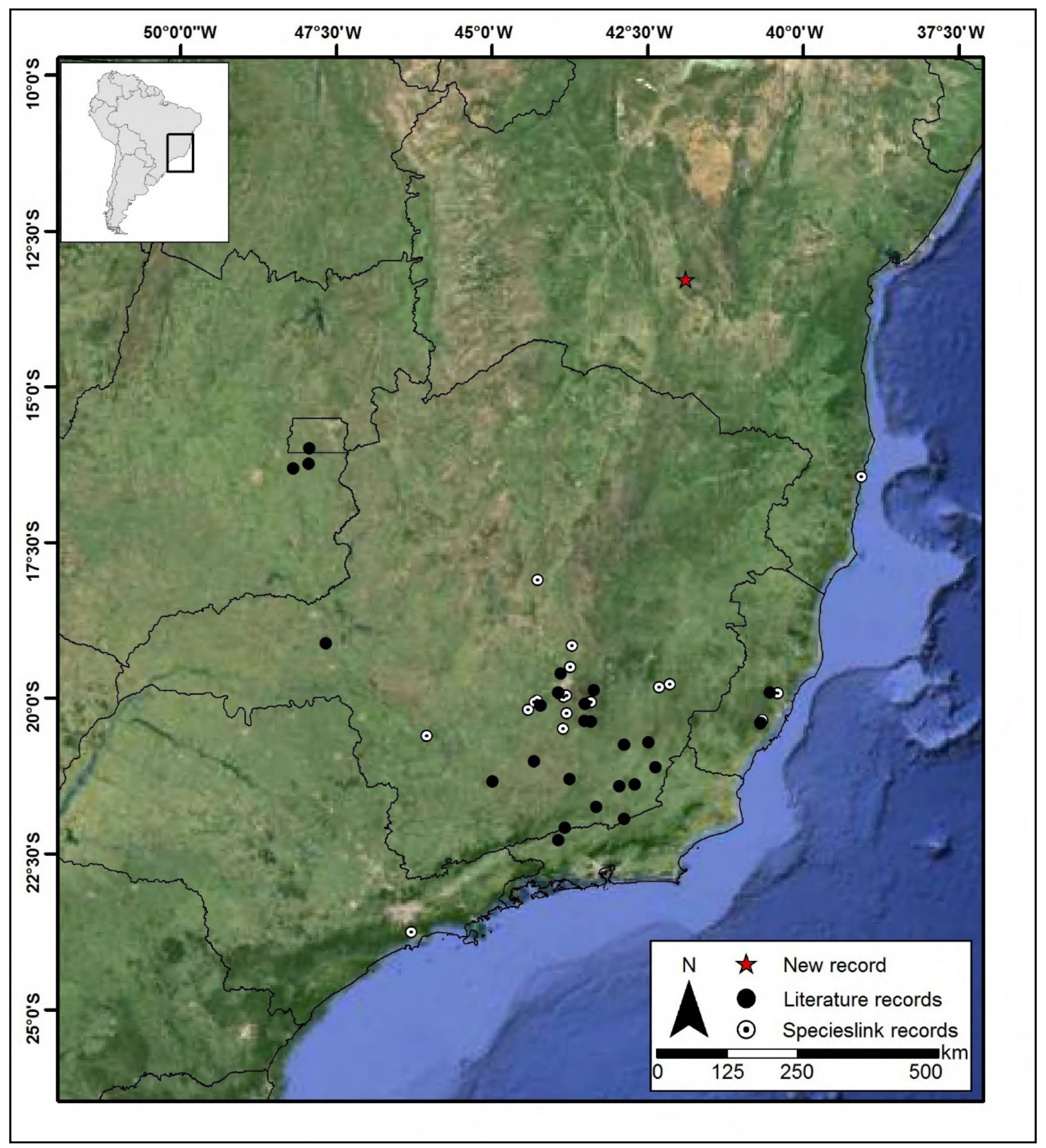

Figure 3. Geographic distribution of Enyalius bilineatus in Brazil. Locality names and coordinates are in the Appendix.

database from those obtained by us in the field (Figure 3 ).

This new record extends considerably the known geographic distribution of E. bilineatus, and is the first published record for the species in the Caatinga. The Serra do Barbado is $716 \mathrm{~km}$ from Brasília, Distrito Federal (Cerrado), the closest known locality southwestward, $462 \mathrm{~km}$ from Porto Seguro, Bahia (Atlantic forest), the closest known locality southeastward, and $590 \mathrm{~km}$ from Augusto de Lima, Minas Gerais (Cerrado), the closest known locality southward. The Chapada Diamantina plateau has many relictual ecosystems, including campos rupestres, gallery forests, and other phytophysiognomy of cerrado, suggesting a past contact between the Cerrado and Atlantic Forest (Juncá et al. 2005). The occurrence of E. bilineatus, which was previously known to occur in the Cerrado and Atlantic Forest, in the Chapada Diamantina is similar to the distribution pattern found for some snake species in highland areas 
of the Caatinga (Guedes et al. 2014). These relatively restricted and isolated highland areas are critical for understanding herpetofaunal diversity patterns in the Caatinga, and historical processes influencing their differentiation (Guedes et al. 2014).

\section{ACKNOWLEDGEMENTS}

This study had financial support from the Biodiversity Research Program - PPBio Semiarid/CNPq (Process No: 457463/2012-O), and research grants from the Conselho Nacional de Desenvolvimento Científico e Tecnológico (CNPq) to EMXF (Process No 309424/2011-9), and from the Coordenação de Aperfeiçoamento de Pessoal de Nivel Superior (CAPES) to RFDS. We thank Ricardo Ramos and Jessica Ferreira for the distribution map, and Miguel T. Rodrigues for confirming the identifications.

\section{LITERATURE CITED}

Bertolotto, C.E.V. 2006. Enyalius (Leiosauridae, Squamata): o que os dados moleculares e cromossômicos revelam sobre esse gênero de lagartos endêmico do Brasil [PhD thesis]. São Paulo: Universidade de São Paulo. 129 pp.

Bertoluci, J., M.A.S. Canelas, C.C. Eisemberg, C.F.S. Palmuti and G.G. Montingelli. 2009. Herpetofauna da Estação Ambiental de Peti, um fragmento de Mata Atlântica do estado de Minas Gerais, sudeste do Brasil. Biota Neotropica 9(1): 147-155. doi: 10.159o/ S1676-06032009000100017

Borges, V.S., R.C. Pires, A.M. Linares and P.C. Eterovick. 2013. Diet of Enyalius bilineatus (Leiosauridae: Squamata) at a site in southeastern Brazil: effects of phylogeny and prey availability. Journal of Natural History 47(43-44): 2785-2794. doi: 10.1080/ 00222933.2013 .802048

Costa, H.C., V.D. Fernandes, A.C. Rodrigues and R.N. Feio. 2009. Lizards and amphisbaenians, municipality of Viçosa, state of Minas Gerais, southeastern Brazil. Check List 5(3): 732-745. http://www.checklist.org.br/getpdf?SL131-08

Guedes, T.B., C. Nogueira and O.A.V. Marques. 2014. Diversity, natural history, and geographic distribution of snakes in the Caatinga, Northeastern Brazil. Zootaxa 3863(1): 1-93. doi: 10.11646/zootaxa.3863.1.1

Gomides, S.C. and B.M. Sousa. 2012. Levantamento preliminar da herpetofauna da Serra do Relógio, Minas Gerais, sudeste do Brasil. Revista Brasileira de Zoociências 14(1-3): 45-56. http://zoociencias.ufjf.emnuvens.com.br/zoociencias/article/ view/1201

Juncá, F.A., L. Funch and W. Rocha. 2005. Biodiversidade e conservação da Chapada Diamantina. Brasília: Ministério do Meio ambiente. $436 \mathrm{pp}$.

Jackson, J.F. 1978. Differentiation in the genera Enyalius and Strobilurus (Iguanidae): implications for Pleistocene climatic changes in eastern Brazil. Arquivos de Zoologia 30(1): 1-79. doi: 10.11606/issn.2176-7793.v30i1p1-79

Moura, M.R., A.P. Motta, V.D. Fernandes and R.N. Feio. 2012. Herpetofauna da Serra do Brigadeiro, um remanescente de Mata Atlântica em Minas Gerais, sudeste do Brasil. Biota Neotropica 12(1): 209-235. doi: 10.1590/S1676-06032012000100017

Nogueira, C.C. 2011. New records of Squamata reptiles in central Brazilian Cerrado II: Brasília region. Herpetological Review 32(4): $285-287$.

Nogueira, C., S. Ribeiro, G.C. Costa and G.R. Colli. 2011. Vicariance and endemism in a Neotropical savanna hotspot: distribution patterns of Cerrado squamate reptiles. Journal of Biogeography
38: 1907-1922. doi: 10.1111/j.1365-2699.2011.02538.x

Novelli, I.A., P.S. Lucas, R.G. Carvalho, R.C. Santos and B.M. Sousa. 2012. Lagartos de áreas de Cerrado na Reserva Biológica UnilavrasBoqueirão, Ingaí, sul de Minas Gerais, Brasil. Biota Neotropica 12(2): 147-153. doi: 10.1590/S1676-06032012000300017

Rodrigues, M.T., M.A. Freitas, T.F.S. Silva and C.E.V. Bertolotto. 2006. A new species of lizard genus Enyalius (Squamata, Leiosauridae) from the highlands of Chapada Diamantina, state of Bahia, Brazil, with a key to species. Phyllomedusa 5(1): 11-24. http://www.phyllomedusa.esalq.usp.br/articles/volume5/ number1/511124.pdf

Rodrigues, M.T., C.E.V. Bertolotto, R.C. Amaro, Y. Yonenaga-Yassuda, E.M.X. Freire and K.C.M. Pellegrino. 2014. Molecular phylogeny, species limits, and biogeography of the Brazilian endemic lizard genus Enyalius (Squamata: Leiosauridae): an example of the historical relationship between Atlantic Forests and Amazonia. Molecular Phylogenetics and Evolution 81: 137-146. doi: 10.1016/j.ympev.2014.07.019

Sousa, B.M., A.E.R. Nascimento, S.C. Gomides, C.H. Varela Rios, A.H. Hudson and I.A. Novelli. 2010. Répteis em fragmentos de Cerrado e Mata Atlântica do Campo das Vertentes, Estado de Minas Gerais, sudeste do Brasil. Biota Neotropica 10(2): 129-138. doi: 10.1590/S1676-06032012000300002

SpeciesLink. 2015. Distributed information system for biological collections: integrating species analyst and SinBiota (FAPESP). Accessed at www.splink.cria.org.br, 20 May 2015.

Teixeira, R.L., K. Roldi and D. Vrcibradic. 2005. Ecological comparisons between the sympatric lizards Enyalius bilineatus and Enyalius brasiliensis (Iguanidae, Leiosaurinae) from an Atlantic rain-forest area in southeastern Brazil. Journal of Herpetology 39(3): 504-509. doi: 10.1670/9-05N.1

Vanzolini, P.E. 1978. Miscellaneous notes on the ecology of some Brasilian lizards (Sauria). Papéis Avulsos de Zoologia 26(8): 83-115.

Vitt, L.J. and J.P. Caldwell. 2014. Herpetology: An introductory biology of amphibians and reptiles, 4th edition. San Diego: Academic Press. 757 pp.

Zamprogno, C., M.G.F. Zamprogno and R.L. Teixeira. 2001. Evidence of terrestrial feeding in the arboreal lizard Enyalius bilineatus (Sauria, Polychrotidae) of south-eastern Brazil. Revista Brasileira de Biologia 61(1): 91-94. doi: 10.1590/So034-71082001000100012

Author contributions: RFDS collected the data in the field, made the literature review, organized the geographic coordinates, and wrote the text; LBR collected the data in the field and revised the text; EMX Freire identified the species and revised the text.

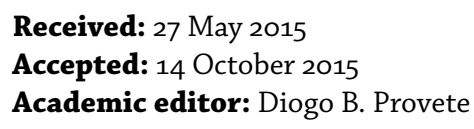

\section{APPENDIX}

Geographic coordinates (latitude and longitude in decimal degrees) of the literature records for Enyalius bilineatus.

BRAZIL: BAHIA: Arraial D’Ajuda, Porto Seguro (16.4497 S, $039.0647^{\circ}$ W; SpeciesLink database, MBML-Répteis 1023-1024); Serra do Barbado, Abaíra ( $13.2874^{\circ} \mathrm{S}$, $041.8905^{\circ} \mathrm{W}$; this study); Distrito Federal: Brasília, Brazilian Navy Training Area $\left(16^{\circ} \mathrm{S}\right.$, $047.9333^{\circ} \mathrm{W}$; Nogueira 2011); GoIÁs: Luziania ( $16.248^{\circ} \mathrm{S}$, $047.945^{\circ} \mathrm{W}$; Bertolotto 2006); UHE Corumbá IV ( $16.3206^{\circ} \mathrm{S}$, $048.1879^{\circ} \mathrm{W}$; Rodrigues et al. 2006); Espírito SANTO: Alto Rio Saltinho, Santa Teresa $\left(19.916^{\circ}\right.$ S, $040.533^{\circ} \mathrm{W}$; Teixeira et al. 2005; Campinhos, Domingos Martins $\left(20.3633^{\circ} \mathrm{S}, 040.6591^{\circ} \mathrm{W}\right.$; SpeciesLink database, MBML-Répteis 
2020); Goiapabu Açu, Fundão (19.9325 S, $040.4066^{\circ}$ W; SpeciesLink database, MBML-Répteis 683); Sítio 3 Marias, Alto Santa Maria, Marechal Floriano (20.4127 $\mathrm{S}$, $040.683^{\circ} \mathrm{W}$, Zamprogno et al. 2001; Minas GeraIs: Antônio Carlos (21.31 ${ }^{\circ} \mathrm{S}$, $043.75^{\circ} \mathrm{W}$; Jackson 1978); Belo Horizonte ( $19.923^{\circ} \mathrm{S}$, $043.933^{\circ} \mathrm{W}$; Bertolotto 2006); Benjamim Constant (21.947 ${ }^{\circ} \mathrm{S}, 042.874^{\circ} \mathrm{W}$; Jackson 1978); Bom Jesus do Galho (19.8289 $\mathrm{S}$, $042.3161^{\circ} \mathrm{W}$; SpeciesLink database, UFMG-

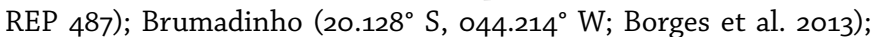
Capitólio $\left(20.615^{\circ} \mathrm{S}, 046.05^{\circ} \mathrm{W}\right.$; SpeciesLink database, MCP-Répteis 18854); Catas Altas (20.0747 $\mathrm{S}$, $043.4075^{\circ} \mathrm{W}$; SpeciesLink database,

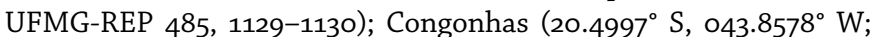
SpeciesLink database, UFMG-REP 1049, 1730-1731, 2025-2026); Estação Ambiental de Peti $\left(19.883^{\circ} \mathrm{S}\right.$, $043.358^{\circ} \mathrm{W}$; Bertoluci et al. 2009); Fazenda Serra do Cabral Azul, Augusto de Lima (18.1092 ${ }^{\circ} \mathrm{S}$, $044.2669^{\circ} \mathrm{W}$; SpeciesLink database, UFMG-REP 1638, 1640-1641); Fragmento Oswaldo, Caratinga ( $19.7897^{\circ} \mathrm{S}$, $042.1392^{\circ} \mathrm{W}$; SpeciesLink database, UFMG-REP 1093, 1607-1608); Juiz de Fora (21.76 $\mathrm{S}$, 043.323 ${ }^{\circ} \mathrm{W}$; Jackson 1978); Lagoa Santa ( $19.618^{\circ} \mathrm{S}$, $043.899^{\circ} \mathrm{W}$; Jackson 1978); Mariana (20.382 ${ }^{\circ}$ S, $043.409^{\circ} \mathrm{W}$; Jackson 1978; Vanzolini 1978); Muriaé (21.12 $\mathrm{S}$, $042.369^{\circ} \mathrm{W}$; Jackson 1978); Nova Lima $\left(19.9856^{\circ} \mathrm{S}\right.$, $043.8467^{\circ} \mathrm{W}$; SpeciesLink database, UFMG-REP 481, 49o, 956); Nova Ponte (19.133 ${ }^{\circ} \mathrm{S}, 047.666^{\circ} \mathrm{W}$; Bertolotto 2006);
Ouro Preto (20.377 S, $043.512^{\circ} \mathrm{W}$; Jackson 1978); Parque Estadual da Serra do Brigadeiro (20.716 $\mathrm{S}$, $042.482^{\circ} \mathrm{W}$; Moura et al. 2012); Raposos (19.9672 $2^{\circ}$, $043.8042^{\circ} \mathrm{W}$; SpeciesLink database, UFMG-REP 1953, 1955-1958); Reserva Biológica Unilavras-Boqueirão (21.346 ${ }^{\circ} \mathrm{S}$, 044.991 ${ }^{\circ} \mathrm{W}$; Novelli et al. 2012); Rio Preto $\left(22.086^{\circ} \mathrm{S}\right.$, $043.829^{\circ} \mathrm{W}$; Jackson 1978); Ritápolis (21.027 S, $044.32^{\circ} \mathrm{W}$; Sousa et al. 2010); RPPN Alto da Boa Vista, Descoberto (21.424 ${ }^{\circ} \mathrm{S}$, $042.953^{\circ} \mathrm{W}$; Gomides et al. 2012); Santana do Riacho $\left(19.1689^{\circ} \mathrm{S}, 043.7144^{\circ} \mathrm{W}\right.$; SpeciesLink database, UFMG-REP 489); Sereno, Cataguases (21.391 ${ }^{\circ} \mathrm{S}, 042.703^{\circ}$

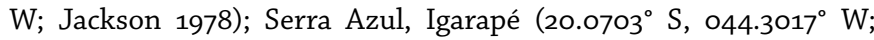
SpeciesLink database, UFMG-REP 1381, 1730, 1852, 1854, 1857, 1867); Serra Azul, Itataiuçu $\left(20.1967^{\circ} \mathrm{S}, 044.4211^{\circ} \mathrm{W}\right.$; SpeciesLink database, UFMG-REP 903, 1847, 1866); Serra Azul, São Joaquim de Bicas $\left(20.0492^{\circ} \mathrm{S}, 044.2739^{\circ} \mathrm{W}\right.$; SpeciesLink database, UFMG-REP ${ }^{1855^{-}}$ 1856); Serra da Moeda, Itabirito $\left(20.2533^{\circ} \mathrm{S}, 043.8014^{\circ} \mathrm{W}\right.$; SpeciesLink database, UFMG-REP 1910); Serra do Caraca, Santa Bárbara (20.1 ${ }^{\circ} \mathrm{S}$, 043.5 W; Jackson 1978); Serra do Cipó, Jaboticatubas (19.5136 ${ }^{\circ} \mathrm{S}$ $043.745^{\circ} \mathrm{W}$; SpeciesLink database, UFMG-REP 480); Viçosa (20.756 S, $042.871^{\circ} \mathrm{W}$; Jackson 1978; Costa et al. 2009); RIO DE JANEIRO: Conservatória (22.291 ${ }^{\circ} \mathrm{S}$, $043.931^{\circ} \mathrm{W}$; Jackson 1978); SÃO PAULO: Parque Municipal Águas de Paranapiacaba, Santo André (23.7691 ${ }^{\circ}$ S, 046.2954 W; SpeciesLink database, UFMG-REP 886). 